\title{
Correlation Analysis of Interpersonal Communication Competence of Corporate Social Responsibility Facilitators, Stakeholder Trust Level, and Corporate Reputation
}

\author{
Retno Wulandari ${ }^{a, 1^{*}}$, Agus Naryoso ${ }^{\mathrm{b}, 2}$, Arifa Rachma Febriyani ${ }^{\mathrm{c}, 3}$, Siti Ahmaniyar ${ }^{\mathrm{d}, 4}$ \\ ${ }^{a}$ Ahli Muda Community Development PT Indonesia Power Semarang PGU \\ a,b,c dUniversitas Diponegoro \\ Email: 'retnowulandari@indonesiapower.co.id, ${ }^{2}$ agusnaryoso@gmail.com*, ${ }^{3}$ arifafebriyani@gmail.com, ${ }^{4}$ sitiahmaniar98@gmail.com \\ *corresponding author
}

\author{
Keywords: \\ PT. Indonesia Power Semarang \\ PGU, Corporate Social \\ Responsibilit, Interpersonal \\ Communication Competence
}

\begin{abstract}
The problem of communication such as misunderstanding, there is no feedback, and the ineffectiveness of a message often occurs while the company communicates or interacts with stakeholders, moreover runs the CSR program. The communication problems above affected one of the CSR goals. CSR can improve people living in the region around the company like happened in the District of North Semarang because it has the highest poverty rate in Semarang city. Not achieving the CSR objectives will because residents who live around the company have poor judgments against the company and have no trust against the company and so, causes a poor reputation against the company. Moreover, if the company has excessive gas emission and one of them is PT. Indonesia Power Semarang PGU. The research has the purpose of determining if there is a relationship between the effectiveness of interpersonal communication done by the facilitator of CSR and the level of trust beneficiaries with the reputation company of PT. Indonesia Power Semarang PGU. This research is a quantitative research using the theory of communication effectiveness and reasoned action (TRA). Sample this research is Group guidance of PT. Indonesia Power Semarang PGU is the Joint Business Group (KUB) Prima Indosutera in the District of North Semarang. Based on the research results, the effectiveness of interpersonal communication and trust beneficiaries' level significantly relates to its reputation. The things above showed through the significance value of the hypothesis test performed, more effectively the communication interpersonal has done so. The company's reputation is better (positive) than such a hypothesis has a significance value of $0.000(0.000 \mathrm{~s}$ of $0.01)$.
\end{abstract}

Copyright (C) 2021 Channel Jurnal Komunikasi. All right reserved.

\section{INTRODUCTION}

According to Kriyantono (2015), Corporate Social Responsibility (CSR) activities show the company's commitment to addressing social problems that occur in society, which is part of its work program. This activity is an effort by the company to improve the community's welfare through increased economic capacity, primarily focusing on the communities around its location. The goals unachieved goals only provide benefits-oriented towards the target's welfare and offer strategic benefits to the company, such as legitimacy and operational guarantees. Here is also an assumption that CSR is a logical philanthropic tool for companies that make positive consumer decisions about the company. This assumption conveys the "good deeds" of the company as an effort to gain profits solely to create social welfare around them (Carroll and Shabana, 2010; Taghian et al., 2015).

According to Susanto, the benefits that companies will obtain if companies carry out social responsibility activities consistently reduce the risk of threats and security disturbances and baseless accusations or slander related to the impact of company operations. CSR is one of the safeguards strategies when the company experiences an unsustainable situation, 
profitable, or faced with a crisis (Syahriani \& Siwi, 2018). A crisis is a difficult situation that will have a significant impact on business. Besides, CSR is also very effective in building a solid identity and employee pride. They work for a company with a strong capital structure and participate in consistently handling public problems. CSR is also an effective communication medium in building a harmonious relationship between the company and its stakeholders. The perceptions desired by the company find similarities with the perceptions expected by stakeholders. Suitable CSR activities will also impact the sale of goods or services and bring significant profits. Companies are increasingly expected to behave ethically and socially responsibly. Management officials are also likely to have the competence and skills to deal with various issues, including equality, sustainability, and ethics (Salim, 2018).

CSR goals, as mentioned above, are still a challenge for several companies. The reality in the field shows that many companies still carry out CSR activities that are not on target. Only following the company's wishes but not looking carefully at the needs of potential beneficiaries. CSR activities are carried out only to fulfill and invalidate regulatory obligations. This reality ultimately leads to a condition in which the company does not get any profit. The public attitude expected to be optimistic after being given CSR assistance is still negative because it does not answer stakeholders' needs. This negative attitude is indicated by protests from residents, such as road blockades because transporting raw materials is considered to have damaged public facilities. Even anarchists act in the form of demonstrations that destroy company facilities and theft of company assets.

Retnaningsih (2015) describes several examples of problems in the implementation of CSR in the country. Its is including social conflicts between companies and residents related to customary violations, claims filed by the community due to environmental damage caused by company operations, increasingly pronounced economic disparities, to CSR implementation. that is uneven and unsustainable. Also, Rasyid et al. (2019) stated that top-down communication between companies and beneficiaries is also a CSR problem that often arises. This explanation indicates that the company's CSR activity planning does not involve the beneficiaries. There is no dialogue to listen to what the company can accommodate the beneficiaries' needs through the design of CSR activities.

Several studies reveal how vital a communication strategy is to support a company's CSR activities' success. Kim (2018) examines CSR communication in the United States and formulates a model of the relationship between CSR communication, knowledge, trust, and consumer engagement with company reputation. This model illustrates that effective CSR communication will meet consumer expectations through openness and personal relevance based on facts that arise from established communication, which can increase knowledge and trust and consumer commitment to corporate CSR activities. In turn, effective CSR communication will encourage creating a positive corporate reputation (Kim, 2018).

Business people, even CSR practitioners, do not realize the above facts. They are competing to carry out CSR activities, but it is limited to carrying out appeals made by the government not to be subject to sanctions or reprimands. Many CSR research is carried out but studies mainly from the correlation between activities carried out and business profits. Some look from the point of view of business reputation. There is not much research trying to explore in-depth whether other factors related to CSR activities affect reputation. Business.

The facilitator's role is very significant as an intermediary for communication in CSR activities, but unfortunately, this position has not been given much attention by CSR actors. CSR activities that are carried out even run without the presence of a facilitator. The company appoints the facilitator to help initiate and map the needs of potential beneficiaries of its CSR activities. However, many companies do not use facilitators in implementing CSR activities. The reasons vary from unsupported human resources to limited funds. A CSR facilitator's presence will make CSR activities more suitable to the recipient's needs to run smoothly. Facilitators work from the start, seeking information and communicating with potential beneficiaries about the most appropriate form of assistance. Besides, it also sounds intensive if recipients of aid in practice encounter many obstacles, provide recommendations for solutions, and even facilitate submitting complaints to aid providers.

Golob and Podnar (2014) and Amaladoss and Manohar (2013) argue that CSR communication's effectiveness is significant to measure and evaluate its impact. Communication-based on dialogue and discussion between the company and stakeholders will help promote company legitimacy through its CSR activities. Therefore, it is not surprising that CSR communication is seen as one of the factors supporting the success of the company's CSR activities because it can minimize misunderstandings that have the potential to arise on the part of stakeholders (Dimitrova, 2019). Companies engaged in providing electricity in Tanjung Mas Village, North Semarang District, namely PT, face the challenges of implementing CSR activities. Indonesia Power Semarang PGU. The Central Bureau of Statistics (Badan Pusat StatistikBPS) on its website records 5,323 families in the northern region of Semarang as inferior with pre-prosperous status. This data is also reinforced by data from the Semarang City Social Service. Facts processed by the Integrated Social Welfare Data Statistics (Data Terpadu Kesejahteraan Sosial-DTKS) as of January 2020 reveal that the percentage of poverty in North Semarang is the highest in Semarang City. Poverty is data that describes the number of families and people categorized as poor, with a limited level of family income and inadequate housing. 
Following the problems mentioned above, PT. Indonesia Power Semarang PGU realizes the importance of recognizing concern for the surrounding community and the Prima Indosutera Joint Business Group (KUB) by improving the community's economic and social welfare in Tanjung Mas Village North Semarang District. Motivation is looking for the company's good name and securing long-term business and legal obligations and efforts to build good relationships with the surrounding community_-besides, PT. Indonesia Power Semarang PGU, through strategic CSR activities, wants to get a gold category in the PROPER Award. PT. Indonesia Power Semarang PGU is still ranked in the green variety, wherein that ranking the company's CSR programs has not been able to develop the community sustainably. Therefore, getting a positive assessment from the beneficiaries is needed by PT. Indonesia Power Semarang PGU to continue its business continuity. This fact needs to be supported by an effective communication strategy. This study seeks to analyze the relationship between CSR facilitators' interpersonal communication competence, the level of trust of stakeholders, and the company's reputation. Facilitator communication competence is rarely or even very little discussed in the research literature. Most of the research conducted assessments and measurements on CSR activities and their benefits to the company. In contrast, when examined in-depth, the facilitator has a strategic role in supporting CSR's success.

\section{LITERATURE REVIEW}

\section{A. Effectiveness of CSR Facilitator Interpersonal Communication Competencies}

According to Mahmudi (2005), effectiveness is the relationship between the analysis of the output obtained with the planned target. If achievement is high, We can say that an activity is close to practical value. Vice versa, if the goal is not achieved optimally, the action is said to be ineffective.

Effective interpersonal communication is vital for any organization because it is expected to result in information and mutual understanding. Interpersonal communication is effective when there is a balanced exchange of information between the two parties and reaches the same knowledge and experience. Interactions are well established through sending verbal messages reinforced by nonverbal messages, and interpersonal communication is usually carried out in a face-toface context (Devito, 2012). Mulyana (2008) adds that interpersonal communication works well when each individual who is not physically far away can capture verbal signals from spoken words, besides seeing, understanding, and feeling non-verbal messages from faces, gestures, or positions. The body properly and responds as desired.

CSR implementation needs to be supported by a good communication strategy, both to internal and external stakeholders so that CSR activities can take place on target (Syahriani \& Siwi, 2018). A good communication strategy includes the characteristics of an effective communicator and message. Therefore, assistant officers who have good interpersonal competence with the beneficiaries are believed to encourage CSR activities' success. The right CSR communication strategy can grow a company's reputation. The reality is that not many companies have the initiative to bring in facilitators to bridge the interests of the providers and recipients of assistance. Facilitators are required to have good interpersonal communication skills, build open relationships, be open to criticism and have a willingness to be a good listener. The ability to listen actively is one of the most needed interpersonal communication skills. This was also stated by Pope et al. (2008) noted that effective listening and communication skills are closely related to professionalism which is seen as the primary competence of practitioners in various fields (Brown et al., 2020). Active listening skills require empathy, process messages conveyed by speakers carefully, seek to understand and respond to these messages verbally and nonverbally by showing concern.

The quality of good interpersonal communication is measured by using the leading indicators of the humanist approach. This approach includes equality, openness, supportive attitudes, supportive attitudes, and empathy in communicating with stakeholders. The company's wishes or intentions will be achieved optimally, especially equalizing perceptions between the company and the company. Stakeholders. A humanist approach is an approach that emphasizes the balance of roles in communication, no domination, and intervention between participants. This approach provides an opportunity for message recipients to openly and freely provide criticism and response to the messages they receive. The balance of the roles as speaker and listener is divided proportionally when exchanging information. Not only for communication purposes, but the humanistic approach also helps stakeholders to be able to provide feedback in communicating to the company because they feel they get good treatment when communicating with one. The feedback provided by these stakeholders makes communication has special meaning, a program designed by the company. It will undoubtedly be more effective because both parties position themselves as speakers and listeners when communication occurs. The program is designed to suit both parties' needs. In the end, Park \& Dodd (2016) describe that CSR can produce positive impacts, such as positive attitudes towards the company, stronger purchase intentions (Park \& Kang, 2020; David, Kline, \& Dai, 2005; Rim, Park, \& Song, 2018). The relationships built are increasingly solid (Hong, Yang, \& Rim, 2010), and positive financial growth (Margolis \& Walsh, 2003). This positive impact is inseparable from its efforts to establish open two-way communication through dialogue with the public. Thus, CSR facilitators' interpersonal communication skills are also an essential factor that cannot be ignored in supporting the successful implementation of the program. It is in line with the needs and expectations of the beneficiaries. 


\section{B. Beneficiary Confidence Level}

According to Morgan and Hunt, trust is strongly connected to emotional bonding, which is the belief that is owned in the form of an assessment of an object being able to properly carry out its role and function (Suhardi, 2005). Trust is seen as an essential factor supporting organizational functions (Goodsell, 2006) and builds legitimacy (Bouckaert \& Walle, 2003; Mitchell \& Scott, 1987). According to Dirks and Ferrin (2002), trust is developed based on ethical values and organizational values (Yadav et al., 2018).

A company that is perceived as having a high level of trust is a company that is capable of maximally and competently managing its business activities. The company pursues profit achievement targets and considers aspects of business ethics and compliance with laws or government recommendations. Trust is an expression of judgment from the parties involved in the interaction, namely between stakeholders and the company. Companies are believed to be able to play their business and social roles well proportionally.

In another context, trust also questions the company's value as a company that never deceives the public, does not propagate, acts pretty, does not discriminate, resolves problems with results that benefit both parties. Besides that, the company also assesses and appreciates proportionally free from personal closeness and close people. The company is considered not half-hearted but is very serious about carrying out its CSR programs, not merely pursuing popularity and publicity.

CSR towards the community tends to stimulate social relations between the organization and its customers. The research group in the marketing field revealed that these social relationships are operationalized primarily through customer trust. Gauzente \& Fenneteau (2006) defines trust as the presence of a relationship where customers believe in and the company's integrity. CSR that the company communicates well is expected to build the beneficiaries' public trust (Glaveli, 2020).

\section{The reputation of PT. Indonesia Power Semarang PGU}

The company's reputation is related to the reflection of collective perceptions of current, past, and future company performance, reflecting the company's attractiveness in the eyes of stakeholders (Fombrun, 1996; Mukasa et al., 2015). Reputation is straightforward and straightforward can be understood as recognition of a good name that arises because of the assessment, belief, and general view that a person or a subject has certain qualities. Strong character, and abilities that are seen, tested and can be felt and recognized by the community or stakeholders. (Warta, 2017). Every company will try its best every day in building a positive corporate reputation among stakeholders. The company's reputation is an assessment of all stakeholders regarding the organization's performance, is a generalization of the evaluation and views of the stakeholders as a whole. A good reputation defines the quality and guaranteed development of the company's prospects. A reputation is a form of physical and non-material support from all stakeholder components after comparing its main competitors.

Baalbaki \& Guzman's (2016) research shows that a positive reputation is essential to maintain a company's brand (Swaen et al., 2020). Besides, an optimistic company's reputation can build brand equity (Heinberg, Ozkaya, \& Taube, 2018) and positively impact its relationship with its stakeholders (Cowan \& Guzman, 2020).

Fombrun (2005) suggests that companies can build a reputation through CSR initiatives (Pham \& Tran, 2020). When a company exhibits socially responsible behavior, it gains legitimacy in the public's eyes so that their assessment of the company is positively influenced. To be aware of the public's CSR involvement, companies need to communicate with the public about their CSR activities.

According to Fombrun (2012) in "The Building Block of Reputation" or by Harris Harris Interactive Inc. mentioning the indicators in the reputation assessment or called the Six Dimensions of Reputation. Fombrun and Haris used these six aspects as indicators to assess or reputation measurement instruments known as The Reputation Quotient $\rightarrow(\mathrm{RQ} \rightarrow)$. This concept shows that reputation is a measurable and not abstract achievement. The following are the six aspects that are detailed and elaborated by 20 indicators (Warta, 2017):

\section{Emotional appeal}

This concept relates to the extent to which the company is very charming among stakeholders. Decisions are always awaited, feel proud to have had interaction experience, always consider the initiative to be good without tendency, are considered the best compared to service, have quality service, and always have different breakthroughs.

2. Products and services

The resulting product has good quality, a small potential for damage, minimal negative impact, and good aftersales service.

3. Financial performance

Impressive financial performance, the company's profit achievement, which always shows an upward trend, transparency in financial management. The ability to provide programs with sustainable financial support, and constantly developing investment progressively. 


\section{Vision and leadership}

Leaders who have an excellent short and long-term vision and mission, all activities are planned and measured, have communication and managerial skills capable, adaptive and responsive to criticism, and nondiscriminatory in leading a business.

5. The workplace environment is oriented towards a positive work culture. It provides support and appreciation for high-achieving employees, career promotion opportunities are open to employees, provides continuous moral and material support, increases good welfare, and does not enrich oneself.

6. Social Responsibility has a high spirit of social concern by creating continuous CSR activities, placing CSR activities as a strategy to build good relationships with stakeholders, and sincerely and consistently giving to help the surrounding community get out of poverty.

\section{IRESEARCH METHODS}

This research is explanatory research with a quantitative approach. Explanatory research explains the causal relationship between the variables that affect the hypothesis (Sugiyono, 2015). This type of research connects the independent variables, namely the effectiveness of the CSR facilitators' interpersonal communication competence (X1) and the level of trust of the beneficiaries (X2), with the dependent variable, namely the company's reputation of PT. Indonesia Power Semarang PGU (Y). This study involved 30 respondents who received CSR benefits from PT. Indonesia Power Semarang PGU was conducted in a survey using non-random purposive sampling techniques with beneficiaries' criteriaes and interacted with a facilitator. However, before performing the study, the researcher first conducted a presurvey to ensure the questionnaire's feasibility as a research instrument. We then tested the results of the pre-surveyed for validity and reliability. Quantitative data present data processing using SPSS based on the question items in the questionnaire. This data is presented in a frequency distribution table showing the proportion of respondents' ratings.

Validity is a test instrument that can measure data and show that the data is valid. A data is valid if it shows the degree of accuracy between the information on the object and the data that the researcher can collect. The validity test in this study was used with the SPSS program's help by comparing the correlated item-total correlations with the $r$ table value. The data is said to be valid "If the value of $r$ count $>r$ table is positive" (Ghozali, 2018). The validity test must be done to find out whether the questions in the questionnaire to be given to respondents have accuracy and suitability to the variables used in the study.

The value of the $\mathrm{r}$ table is obtained from the significance level $(\alpha)$ of $5 \%(0.05)$ with a degree of freedom (df) using the following formula:

$$
\mathbf{d f}=\mathbf{n}-\mathbf{2}
$$

Explanation:

$\mathrm{n}=$ number of samples

$2=$ two-tail test

The number of samples in this study was 30 respondents. To find out the table's value, the calculation is carried out according to the formula $\mathrm{df}=30-2=28$ with a significance level of 5\% so that the $\mathrm{r}$ table value in this study is 0.361 . Questions and data can be valid if the $\mathrm{r}$ count is greater $(>)$ than 0.361 .

A reliability test is used to measure a questionnaire which is an indicator of a variable or constructs. The questionnaire can be reliable if the respondent provides consistent answers to each of the questions given. Consistent means that respondents' answers to each question are not too far apart, or the difference is very significant. This study's reliability was carried out using the Cronbach Alpha $(\alpha)$ statistical test from the SPSS program (Ghozali, 2016: 47-48). The reliable criterion for a variable is if the Cronbach's Alpha $(\alpha)$ value is $>0.6$. The following is a table of reliability testing for each research variable.

Table 1. Reliability Test

\begin{tabular}{|c|c|c|c|}
\hline \multirow{2}{*}{$\begin{array}{c}\text { Standar } \\
\text { Cronbach's } \\
\text { Alpha } \\
\end{array}$} & \multicolumn{3}{|c|}{ Reliability Test Results of Each Variable } \\
\hline & Variabel & $\begin{array}{c}\text { Cronbach's } \\
\text { Alpha }\end{array}$ & Explanation \\
\hline \multirow[t]{3}{*}{0.6} & $\begin{array}{l}\text { The effectiveness of CSR facilitator communication } \\
\text { competencies }\end{array}$ & 0.971 & Reliable \\
\hline & Beneficiary confidence level & 0.945 & Reliable \\
\hline & $\begin{array}{l}\text { The reputation of PT Indonesia Power Semarang } \\
\text { PGU }\end{array}$ & 0.949 & Variable \\
\hline
\end{tabular}


Based on the table above, it is known that each research variable is declared reliable. This shows that the questionnaire as a research instrument can be reliable because it reflects the respondents' consistent answers. After passing the validity and reliability test, the primary data obtained can test the research hypothesis.

\section{FINDINGS}

The ideal CSR activities are CSR activities oriented to the needs and efforts to solve the target targets' problems, especially those who live in the area or who live close to the company. The scope of the implementation of PT Indonesia Power Semarang PGU's CSR includes Economics (an independent community economic improvement program through the development of Small and Medium Enterprises (UKM), Education (education and skills programs in increasing community capabilities through skills and professional education in communities, schools, and colleges), Environment (environmental innovation program in supporting clean and green power plants, through the collaboration of companies, communities and other institutions such as scouts and the Ministry of Environment and Forestry (KLHK), Health (corporate innovation activities program in improving public health, Women's Empowerment skills, maternal and child health and business development for women).

In the economic sector, empowering the people of Gunungpati sub-district, Semarang City, through Kampung Batik Alam Malon's establishment. PT Indonesia Power Semarang PGU also has a Smart IP program that stands for Indonesia Power - Internship, Assessment and Certification Program, a collaboration between Indonesia Power and the world of Education in preparing skilled workers in power generation. Meanwhile, from the environmental sector, Indonesia Power has a corporate responsibility program for the surrounding environment, including waste banks, making polders so that they do not rob in the surrounding area. Likewise, with health, PT Indonesia Power Semarang PGU also held consultations and free health checks. Meanwhile, for women's empowerment through joint business activities (KUB) of fish and food processing, Kub Prima Indo.

CSR activities of PT. Indonesia Power Semarang PGU has mapped or mapped the beneficiaries' main problems and needs, then determined the size of the priority scale plan related to each existing region or village's potential. Mapping is done to invite groups before becoming fostered partners, groups in the ring one environment, PMK, then village officials, and potential activity companions to discuss problems and needs. After being invited and linked through multi-stakeholder forum activities, the type of assistance agreed by both parties will be determined and then implemented. After the activity runs, every quarter of the semester, the Multi-Stakeholder Forum is conducted again to see whether the program has been running and the activities funded have led to program sustainability innovations. For example, a waste bank is already running and collaborating with food stalls, and then from the waste bank, the results can be used for the elderly posyandu.

CSR activities carried out by the company well are indicators of the success of gold proper. Gold proper is the highest value and certification or recognition given by the government to implement the best CSR activities. PT Indonesia Power Semarang PGU uses the indicator instrument in Proper to determine CSR activities' format to be carried out. PT Indonesia Power Semarang PGU, through its CSR activities, is still in a good green rating. The acquisition of proper green results from evaluations on all CSR activities that have been carried out. The acquisition of value points is in the numbers. In 2020 the company committed so that the points earned can increase to get good gold points.

One of the efforts made is to improve the quality of social mapping results. The results of this stage are believed to present CSR activities that have high use-value for the community. Through the Facilitator, the company will progressively map the potentials related to natural resources and other potentials. For example, in Tambak Lorok, Tanjung Mas, several pond farmers complain that the water is hot. Complaints with potential problems are immediately followed up, then discussed with the facilitator and informed to the urban village to ensure that the problem is reporting the issue and inviting academics directly to provide the best solution.

CSR activities have a comprehensive and essential meaning, especially during a pandemic situation where the impact is tremendous, especially on the quality of the community's economy, thereby increasing the poverty rate in the area closest to the company location. Pandemic conditions like this require companies to be active and take high initiatives in designing the CSR activities needed to help overcome these problems. The facilitator carries out the initial stage to coordinate with the relevant agencies, police, and other agencies to determine the most appropriate assistance type. The facilitator carries out two main activities. The first is Community Relations, namely establishing direct communication with beneficiaries to assist according to needs. Second is Government Relations, establishing communication with local governments as the authority to confirm the most appropriate types and forms of activities. CSR activities carried out by PT Indonesia Power Semarang PGU are oriented towards efforts to create independence so that these activities can run sustainably. The company policy is that the resources involved in these activities must include 20 percent of local people, youth, community leaders, or business actors who have developed earlier. These efforts are made deliberately to create aspects of justice between the giver and the beneficiary. All elements of society are expected to be fully involved and participate. Social mapping and facilitators' presence will dismiss the notion that CSR activities of PT Indonesia Power Semarang PGU are only enjoyed by a small group of people and will be minimized. In essence, all community groups must get positive benefits from the presence of PT. Indonesia Power Semarang PGU in the area. 
Activities carried out with social mapping and facilitator communication positively affected the formation of the beneficiaries' attitude at PT. Indonesia Power Semarang PGU. One of the partners, Batik Alam Malon, considers that the CSR activities carried out really help the community to achieve better economic quality improvements. Family income has increased, although not significantly. The presence of CSR reduces the unemployment rate, especially female productive age workers. Besides, a positive assessment was also given for the CSR initiative of PT. Indonesia Power Semarang PGU in producing contemporary design innovations and following market tastes. One of them is through training in creative batik design ideas and then making electric-style batik, which has a pretty good market response and has been patented to become Kampung Batik Alam Malon's typical batik.

All CSR activities are not given in the form of fresh money but scholarships and community empowerment programs. Community empowerment is also carried out in the form of business education or business to be managed. If the pond farmers manage their ponds, the food managers are also given the training to produce innovative and high market value products and product marketing strategies. From the results of a quantitative survey of the CSR program conducted by PT Indonesia Power, which emphasizes the evaluation of facilitators' communication competence and the level of trust of the beneficiaries and their correlation with the company's reputation, most of the results show positive values. This positive value can be concluded that it has a significant relationship with its reputation - positive Reputation of PT. The many acknowledgments also strengthen Indonesia Power Semarang PGU it has received for company performance, such as ISO 26000 through one of its flagship programs IP Care. The award, which has been obtained from CSR activities carried out by PT Indonesia Power Semarang PGU in 2018, is one of the fostered partners to get the UMKM award. The company fostered partners to get an award. The company will also provide additional incentives for funding assistance, especially those who can carve business achievements and bring the good name of PT. Indonesia Power Semarang PGU.

\section{A. Hypothesis Testing}

This study has two (2) hypotheses that will be tested to determine whether the hypothesis designed at the beginning of the study can prove significant or insignificant. Two (2) hypotheses tested are:

1. H0: $\mu 1$ : There is no positive relationship between the effectiveness of the CSR facilitator's interpersonal communication competence and the company reputation of PT. Indonesia Power Semarang PGU.

2. H0: $\mu 2$ : There is no positive relationship between the trust level of the beneficiaries and the company's reputation. PT. Indonesia Power Semarang PGU.

3. Ha: $\mu 1$ : There is a positive relationship between the effectiveness of the CSR facilitator's interpersonal communication competence and the company's reputation. PT. Indonesia Power Semarang PGU.

4. Ha: $\mu 2$ : There is a positive relationship between the level of trust of the beneficiaries and the company reputation of PT. Indonesia Power Semarang PGU.

Drawing conclusions for testing this hypothesis uses a significance level that is used to determine whether there is a relationship between variables referring to the criteria below (Sugiyono, 2015: 164):

1. $\mathrm{H} 0$ is accepted if the significance value is greater than 0.05

2. $\mathrm{H} 0$ is rejected if the significance value is smaller than 0.05

According to Sujarweni (2014), the closeness of the correlation can be seen through the following grouping:

1. 0.00 to 0.20 means that the closeness of the correlation is very weak

2. 0.21 to 0.40 means that the correlation is weak

3. 0.41 to 0.70 means a strong correlation

4. 0.71 to 0.90 means that the correlation is robust

5. means perfect correlation

a. The Relationship between the Effectiveness of the Communication Competence of the CSR Facilitators and the Reputation of PT. Indonesia Power Semarang PGU

Tabel 2. Kendall's Tau B Test Results between the Effectiveness of the CSR Facilitator's Communication Competence and the Company's Reputation of PT. Indonesia Power Semarang PGU

\begin{tabular}{llllr}
\hline & & Correlations & \\
\hline & & $\begin{array}{l}\text { Effectiveness of Interpersonal } \\
\text { Communication }\end{array}$ & $\begin{array}{l}\text { Positif } \\
\text { Reputation }\end{array}$ \\
\hline Kendall's tau_b & $\begin{array}{l}\text { Effectiveness of Interpersonal } \\
\text { Communication }\end{array}$ & Correlation Coefficient & 1.000 & $.685^{* *}$ \\
\hline
\end{tabular}




\begin{tabular}{rrr}
\hline & & \\
& Sig. (2-tailed) & .000 \\
\hline & $\mathrm{N}$ & 30 \\
\hline Positif Reputation & Correlation Coefficient & $.685 *$ \\
\hline & Sig. (2-tailed) & .000 \\
\hline & $\mathrm{N}$ & 30 \\
\hline
\end{tabular}

The table above is a significance test table to determine whether the hypothesis designed at the beginning of the study is significant or insignificant. It can be seen from the table that the significance value of the above variable is 0.000 $(0.000 \leq 0.05)$, and the correlation coefficient value in the image above is between 0.41 to 0.70 . Namely, the correlation coefficient value shows the number 0.685 . It can be concluded through this that $\mathrm{H} 0: \mu 1$ is rejected while and Ha: $\mu 1$ is accepted, and the closeness of the correlation between the two variables is intense, and the theory used has relevance and similarity to the results of this study.

\section{b. Relationship between Beneficiary's Trust Level and Reputation of PT. Indonesia Power Semarang PGU}

Table 3 Kendall's Tau B Test Results between Beneficiary Trust Level and Company Reputation PT. Indonesia Power Semarang PGU

\begin{tabular}{lcrrr}
\hline \multicolumn{2}{c}{ Correlations } & & & \\
\hline & & \multicolumn{1}{c}{$\begin{array}{l}\text { Level of } \\
\text { Confidence }\end{array}$} & $\begin{array}{r}\text { Positif } \\
\text { Reputation }\end{array}$ \\
\hline Kendall's tau_b & Level of Confidence & Correlation Coefficient & 1.000 & $.676^{* *}$ \\
\hline & & Sig. (2-tailed) &. & .000 \\
\hline & $\mathrm{N}$ & 30 & 30 \\
\hline Positif Reputation & Correlation Coefficient & $.676^{* *}$ & 1.000 \\
\hline & Sig. (2-tailed) & .000 &. \\
\hline **. Correlation is significant at the 0.01 level (2-tailed) & $\mathrm{N}$ & 30 & 30 \\
\hline
\end{tabular}

The table above is a significance test table to determine whether the hypothesis designed at the beginning of the study is significant or insignificant. It can be seen from the table above that the significance value of the above variable is $0.000(0.000 \leq 0.05)$, and the correlation coefficient value in the image above lies between 0.41 to 0.70 , namely the correlation coefficient value shows the number 0.676. It can be concluded that H0: $\mu 2$ is rejected, and Ha: $\mu 2$ is accepted, and the closeness of the correlation between the two variables is strong, and the theory used has relevance and similarity to the results of this study.

\section{RESULT \& DISCUSSION}

The research results indicate that there is a very significant relationship between the effectiveness of the communication competence of the CSR facilitators and the level of trust of the beneficiaries with the company's reputation of PT. Indonesia Power Semarang PGU. The two independent variables above have a relationship that is directly proportional to the dependent variable, where the higher the effectiveness of the CSR facilitator's communication competence (X1) and the higher the level of trust of the beneficiaries (X2), the better (positive) the reputation of the company PT. Indonesia Power Semarang PGU (Y). The above results can be interpreted that the more effective the facilitators' interpersonal communication, the more company reputation PT. Indonesia Power Semarang PGU will be more positive. Indicators to assess the effectiveness of interpersonal communication by facilitators are the ease of contacting when beneficiaries have problems, willingness to listen to beneficiary complaints, have effective ideas and solutions, and show good assertiveness in communicating, such as not interrupting the conversation and not always blaming decision making by benefit recipients - meanwhile, the positive reputation of PT. Indonesia Power Semarang PGU is measured using a benchmark rating under PT. Indonesia Power Semarang PGU is a future state-owned company that can develop into a company with good business potential. Besides that, it also provides an assessment that the leadership or board of directors of PT. Indonesia Power Semarang PGU is considered to have qualified leadership qualities such as being sensitive to the surrounding community's needs and open to being invited to communicate. 


\section{A. The Relationship between the Effectiveness of the Interpersonal Communication Competence of the CSR Facilitator and the Reputation of PT. Indonesia Power Semarang PGU}

Based on Kendall's Tau B test results, the effectiveness variable of interpersonal communication competence and company reputation of PT. Indonesia Power Semarang PGU obtained a significance value of 0.0000 where the significance level is $<0.05$ so that $\mathrm{H} 0$ is rejected and Ha: $\mu 1$ is accepted. There is a correlation coefficient of 0.685 , which means that the relationship between the two variables of communication competence effectiveness with reputation has a strong enough relationship. The theory of the effectiveness of communication competence interpersonal by Joseph De Vito has relevance and similarity to the research results. In line with the research results that have been done, that $50 \%$ of 30 respondents or 15 people said and assessed the interpersonal communication competence of CSR facilitators from PT. Indonesia Power Semarang PGU is considered very effective. The positive assessment of the interpersonal communication competency effectiveness variable that the CSR facilitator has carried out strengthens the beneficiary's view of PT. Indonesia Power Semarang PGU stated that the company has good quality, competent in establishing interpersonal communication, and building satisfying interactions with beneficiaries. This interaction is a form of positive attitude from society to the company. A positive attitude is an optimistic assessment given by the heir to PT. Indonesia Power Semarang PGU, giving rise to a positive reputation for the company.

\section{B. Relationship between Beneficiary's Trust Level and Reputation of PT. Indonesia Power Semarang PGU}

Based on Kendall's Tau B test results, the effectiveness variable of interpersonal communication competence and company reputation of PT. Indonesia Power Semarang PGU obtained a significance value of 0.0000 where the significance level is $<0.05$. So that $\mathrm{H} 0$ is rejected and Ha: $\mu 2$ is accepted. The correlation coefficient between the two variables of the level of trust and reputation is 0.676 , so it can be said that the two variables have a strong enough relationship. These findings are in line with the substance of the Theory of Reasoned Action (TRA) or the theory of reasoned action, which states that humans behave consciously in considering available information and consider the implications of their actions (Littlejohn \& Foss, 2010: 94). Correlation test data has relevance and similarity to the research results that $50 \%$ of 30 respondents or 15 people said that they have a high level of trust in PT. Indonesia Power Semarang PGU, where a high level of trust from beneficiaries has a positive behavior related to the company, is called a positive reputation. The high level of trust of the beneficiaries reflects the belief in the seriousness of PT. Indonesia Power Semarang PGU in helping the community get out of the problems at hand. Besides, they also believe that the company has the motive to follow the government's recommendations. Still, the company has a good commitment to carry out the sustainability of the CSR programs provided. When beneficiaries believe in the company through the CSR programs, the level of trust will be even stronger. A company with a good CSR design will become a company with a high level of public trust and a very positive company reputation.

\section{CONCLUSION}

The results showed a positive and significant relationship between the effectiveness of CSR's interpersonal communication competence and the company's reputation. PT. Indonesia Power Semarang PGU, this means a strong correlation. This can be seen through the significance value of the hypothesis testing that has been carried out. The first hypothesis has a significance value of $0.000(0.000 \leq 0.01)$, and the correlation coefficient value is 0.685 , so it can be concluded that the theory used. Namely, the effectiveness of interpersonal communication competence, Joseph De Vito, is proven and relevant. for this research or verified

The results showed a positive and significant relationship between the level of trust of the beneficiaries and the company reputation of PT. Indonesia Power Semarang PGU and has a strong correlation. Results can be seen through the significance value of the hypothesis testing carried out. The second hypothesis has a significance value of $0.000(0.000 \leq$ 0.01 ), and the correlation coefficient value is 0.676 . These results can be used to draw the assumption that the theory used in this study is Theory of Reasoned Action (TRA) or can be called the theory of reasoned action proven and relevant for this research or verified.

As a suggestion, it is necessary to conduct further qualitative research by collecting data through in-depth interviews and FGDs regarding the evaluation of the CSR activities of PT. Indonesia Power Semarang PGU and its relevance to the Semarang City Government Strategic Plan with speakers from local government elements.

Companies need to issue Standard Operational Procedures (SOPs) known to the Board of Directors, CSR Implementers, CSR Facilitators, Local Government, and Beneficiaries to get optimal results from the activities carried out.

\section{REFERENCES}

[1] Amaladoss, Martin Xavier \& Manohar, Hansa Lysander. (2013). Communicating Corporate Social Responsibility - A Case of CSR Communication in Emerging Economies. Corporate Social Responsibility and Environmental Management, John Wiley \& Sons, vol. 20(2). pages 65-80, March. DOI: 10.1002/csr.287

[2] Baalbaki, Sally \& Guzmán, Francisco. (2016). A consumer-perceived consumer-based brand equity scale. Journal 
of Brand Management, Palgrave Macmillan, vol. 23(3). pages 229-251, May. DOI: 10.1057/bm.2016.11

[3] Bouckaert, G., Walle, S. Van De. 2003. Quality of Public Service Delivery and Trust in Government. In Governing Networks: EGPA Yearbook (pp. 299-318).

[4] Brown, T., Yu, M., \& Etherington, J. (2020). Are Listening and Interpersonal Communication Skills Predictive of Professionalism in Undergraduate Occupational Therapy Students? Health Professions Education. 6(2). $187-200$. https://doi.org/10.1016/j.hpe.2020.01.001

[5] Carroll, A.B. and Shabana, K.M. (2010). The Business Case for Corporate Social Responsibility: A Review of Concepts, Research, and Practice. International Journal of Management Reviews, 12: 85-105. https://doi.org/10.1 111/j.1468-2370.2009.00275.

[6] Cowan, Kristen \& Guzman, Fancisco. (2020). How CSR reputation, sustainability signals, and country-of-origin sustainability reputation contribute to corporate brand performance: An exploratory study. Journal of Business Research Volume 117, September 2020, Pages 683-693 https://doi.org/10.1016/j.jbusres.2018.11.017

[7] David, Prabu, Kline, Kline \& Dai, Yang. (2005). Corporate Social Responsibility Practices, Corporate Identity, and Purchase Intention: A Dual-Process Model. Journal of Public Relations Research, 17:3, 291-313, DOI: 10.1207/ s1532754xjprr1703_4

[8] Devito, J. A. (2012). The Interpersonal Communication Book (13th edition). Pearson.

[9] Dimitrova, Y. (2019). Communication on Corporate Social Responsibility and Management of Responsible Corporate Reputation. January.

[10] Dirks, K. T., \& Ferrin, D. L. (2002). Trust in leadership: Meta-analytic findings and implications for research and practice. Journal of Applied Psychology, 87(4). 611-628

[11] Fombrun, C.J. (1996). Reputation: Realizing Value from the Corporate Image. Harvard Business School Press, Boston, MA.

[12] Fombrun, C.J. (2005). Building Corporate Reputation through CSR Initiatives: Evolving Standards. Corporate Reputation Review, 8, 7-11. http://dx.doi.org/10.1057/palgrave.crr.1540235

[13] Fombrun, C.J. (2012). The Building Blocks of Corporate Reputation: Definitions, Antecedents, Consequences. The Oxford Handbook of Corporate Reputation Edited by Timothy G. Pollock and Michael L. Barnett DOI: 10.1093/ oxfordhb/9780199596706.013.0005

[14] Gauzente, C. and Fenneteau, H. (2006). Éthique et responsabilité sociale. Que peut-on attendre du marketing? in Rosé, J.-J. (Ed.). Responsabilité sociale de l'entreprise. Pour un nouveau contrat social, Bruxelles, De Boeck, 77-92.

[15] Ghozali, I. (2018). Aplikasi Analisis Multivariate Dengan Program SPSS. Badan Penerbit Universitas Diponegoro.

[16] Glaveli, N. (2020). Corporate Social Responsibility Toward Stakeholders And Customer Loyalty: Investigating The Roles Of Trust And Customer Identification With The Company. Social Responsibility Journal, December 2019. https://doi.org/10.1108/SRJ-07-2019-0257

[17] Goodsell, C. T. (2006). A New Vision For Public Administration. Public Administration Review. 66(4). 623-635.

[18] Golob, Ursa \& Podnar, Klement. (2014). Critical Points Of Csr-related Stakeholder Dialogue In Practice. Business Ethics: A European Review. 23. 10.1111/beer.12049.

[19] Heinberg, Martin \& Ozkaya, H. Erkan \& Taube, Markus. (2018). Do Corporate Image And Reputation Drive Brand Equity In India And China? - Similarities And Differences. Journal of Business Research, Elsevier, vol. 86(C). pages 259-268. DOI: 10.1016/j.jbusres.2017.09.018

[20] Hong, Soo \& Yang, Sung-Un \& Rim, Hyejoon. (2010). The Influence of Corporate Social Responsibility and Customer-company Identification on Publics' Dialogic Communication Intentions. Public Relations Review. 36. 196-198. 10.1016/j.pubrev.2009.10.005.

[21] Keputusan Menteri Lingkungan Hidup dan Kehutanan Republik Indonesia pada hasil Penilaian Peringkat Kinerja Perusahaan (PROPER) dalam Pengelolaan Lingkungan Hidup tahun 2018-2019 (https://proper.menlhk.go.id/ propercms/uploads/magazine/docs/sk/sk-menlhk-nomor-1049-tahun-2019-lengkap.pdf) diakses pada 11 September 2020

[22] Kim, S. (2018). The Process of CSR Communication-Culture-Specific or Universal? Focusing on Mainland China and Hong Kong Consumers. International Journal of Business Communication. https://doi. org/10.1177/2329488418805523

[23] Kriyantono, R. (2015). Public Relations and Corporate Social Responsibility in Mandatory Approach Era in Indonesia. Procedia - Social and Behavioral Sciences, 211(June). 320-327. https://doi.org/10.1016/j.sbspro.2015.11.041

[24] Littlejohn, S. W., \& Foss, K. A. (2010). Theories of Human Communication. Long Grove: Waveland Press.

[25] Mahmudi. (2005). Manajemen Kinerja Sektor Publik. UPP AMP YKPN. 
[26] Margolis, J. D., \& Walsh, J. P. (2003). Misery Loves Companies: Rethinking Social Initiatives by Business. Administrative Science Quarterly. 48(2). 268-305. https://doi.org/10.2307/3556659

[27] MacKenzie, S., Podsakoff, P., \& Fetter, R. (1993). The Impact of Organizational Citizenship Behavior on Evaluations of Salesperson Performance. Journal of Marketing, 57(1). 70-80. doi:10.2307/1252058

[28] Mukasa, K. D., Kim, K., Korea, S., Lim, H., \& Korea, S. (2015). How Do Corporate Social Responsibility? 31(2). 383-396.

[29] Mulyana, D. (2008). Ilmu Komunikasi: Suatu Pengantar. Remaja Rosdakarya.

[30] Park, Young Eun \& Dodd, Melissa. (2016). The Historical Development of Corporate Social Responsibility as a Strategic Function of Public Relations. 10.4324/9781315646503-1.

[31] Park, Y. E., \& Kang, M. (2020). When crowdsourcing in CSR leads to dialogic communication: The effects of trust and distrust. Public Relations Review. 46(1). 101867. https://doi.org/10.1016/j.pubrev.2019.101867

[32] Pope, BB, Rodzen L, Spross G. (2008). Raising the SBAR: How Better Communication Improves Patient Outcomes. Nursing. Mar;38(3):41-3. doi: 10.1097/01.NURSE.0000312625.74434.e8. PMID: 18418180.

[33] Pham, H. S. T., \& Tran, H. T. (2020). Csr Disclosure And Firm Performance: The Mediating Role Of Corporate Reputation And Moderating Role Of Ceo Integrity. Journal of Business Research, 120(August). 127-136. https:// doi.org/10.1016/j.jbusres.2020.08.002

[34] Rasyid, A., Saleh, A., Cangara, H., \& Priatna, W. B. (2019). Jurnal 23 - Pemberdayaan Masy. 31(2). $507-518$.

[35] Retnaningsih, H. (2015). Permasalahan Corporate Social Responsibility (CSR) dalam Rangka Pemberdayaan Masyarakat. Aspirasi. 6(2). 177-188. https://jurnal.dpr.go.id/index.php/aspirasi/article/view/512

[36] Rim, H., Park, Y. E., \& Song, D. (2020). Watch Out When Expectancy Is Violated: An Experiment Of Inconsistent Csr Message Cueing. Journal of Marketing Communications, 26(4). 343-361. https://doi.org/10.1080/13527266.2 018.1523216

[37] Salim, Mufid. (2018). Improving Organizational Attractiveness in Job Choice by Communicating CSR Practices. Jurnal Komunikasi ISKI. Vol. 03 (02). 2018. 76-83 https://doi.org/10.25008/jkiski.v3i2.226

[38] Sugiyono. (2015). Metode Penelitian Kuantitatif, Kualitatif dan R\&D. Alfabeta.

[39] Suhardi, G. (2005). Faktor-Faktor Yang Mempengaruhi Kepercayaan Dan Loyalitas Nasabah Perbankan Di Surabaya. Business and Economics. 9(2). 1-11.

[40] Sujarweni, V. W. (2014). Metode Penelitian: Lengkap, Praktis, dan Mudah Dipahami. Pustaka Baru Press.

[41] Statistik Data Terpadu Kesejahteraan Sosial (DTKS) Dinas Sosial Kota Semarang

[42] (http://dinsos.semarangkota.go.id/statistik/index) diakses pada 11 September 2020

[43] Swaen, V., Demoulin, N., \& Pauwels-Delassus, V. (2020). Impact Of Customers' Perceptions Regarding Corporate Social Responsibility And Irresponsibility In The Grocery Retailing Industry: The Role Of Corporate Reputation. Journal of Business Research. https://doi.org/10.1016/j.jbusres.2020.12.016

[44] Syahriani, D., \& Siwi, M. (2018). Hubungan Komunikasi Corporate Social Responsibility Dengan Reputasi Perusahaan, 16(1). 54-74. https://doi.org/10.29244/jurnalkmp.16.1.54-74

[45] Taghian, M., D’Souza, C., \& Polonsky, M. J. (2015). A Stakeholder Approach To Corporate Social Responsibility, Reputation, And Business Performance. Social Responsibility Journal. 11(2). 340-363. https://doi.org/10.1108/ SRJ-06-2012-0068

[46] Warta, W. (2017). Manajemen Reputasi. Simbiosa Rekatama Media.

[47] Yadav, R. S., Dash, S. S., Chakraborty, S., \& Kumar, M. (2018). Perceived CSR and Corporate Reputation: The Mediating Role of Employee Trust. Vikalpa. 43(3). 139-151. https://doi.org/10.1177/0256090918794823 
